\title{
Is Students' Satisfaction in Electrical Engineering Courses Influenced by Gender?
}

\author{
Celina P. Leão ${ }^{1}$, Filomena Soares ${ }^{2}$ \\ ${ }^{1}$ Department of Production Systems, Centre Algoritmi \\ ${ }^{2}$ Department of Industrial Electronics, Centre Algoritmi \\ University of Minho, Guimarães, Portugal
}

\author{
Anabela Guedes ${ }^{3}$, M. Teresa Sena Esteves ${ }^{3}$, \\ Gustavo Alves ${ }^{3}$, Isabel M. Brás Pereira ${ }^{3}$ \\ ${ }^{3}$ Centro de Inovação em Engenharia e Tecnologia Industrial \\ Instituto Superior de Engenharia do Porto, Porto, Portugal
}

\author{
Romeu Hausmann ${ }^{4}$, Clovis António Petry 5 \\ ${ }^{4}$ Universidade Regional de Blumenau, Blumenau \\ ${ }^{5}$ Instituto Federal de Santa Catarina, Florianópolis \\ Brazil
}

tertiary qualification was already higher than that of men [1,2].

In spite of this impressing movement, gender differences still exist in educational and employment issues, mainly in certain specific fields. Men traditionally dominate Science, computing and engineering whereas education, social sciences and health care typically attract more women [2]. Given this discrepancy between the different fields of knowledge, many studies have been presented during the last decades in order to assess the tendencies of boys and girls in the different cognitive domains, but also to understand the factors that may be responsible for some of those genders based differences. The studies may be focused in high school or in higher education, in all fields or in specific fields. Many times, the gender factor is one of the various factors that are analyzed. Since education and specifically higher education is deeply related to a future professional career, in some studies the relationships between the educational factors and the professional outcomes are also assessed [3-15].

Kim and Sax [3] have taken a large research university system to analyze the effects of six different forms of studentfaculty interaction on several outcomes (grade point average (GPA), degree aspiration, integration, critical thinking and communication, cultural appreciation and social awareness, and satisfaction with overall college experience) considering different student characteristics: gender, race, social class, and first-generation status. Two specific objectives were also to understand how those characteristics affect the frequency of student-faculty interaction and the student satisfaction with faculty contact. The data used in the study refer to 58,281 undergraduate students ( $54.1 \%$ female) who participated in the 2006 University of California Undergraduate Experience Survey (UCUES). For some of the statistical analyses, the sample was limited to 11,928 students. Gender differences were statistically significant on five forms of student-faculty interaction. For research-related faculty contact, male students developed research as a volunteer or for pay, and females did it mainly for course credit. For both genders and without significant differences in the effects for female and male students, that kind of interaction significantly and positively 
predicted their higher college GPAs, higher degree aspirations, and larger gains in critical thinking and communication. Only for female students that type of interaction also enhanced their integration in the campus and respective perception. For course-related faculty contact, female students reported a more frequent communication by email or personal, whereas males preferred to interact during lecture class sessions. Female students show to be more satisfied than their male mates with the interaction with faculty. Course-related student-faculty interaction related to higher college GPAs, larger gains in critical thinking and communication, and greater satisfaction with overall college experience for both female and male students. This interaction was also positively related with student degree aspiration for both genders, being significantly stronger for male students. Male students also benefit significantly and exclusively from the effects of course-related student-faculty interaction on their integration and in social awareness.

The OECD Program for International Student Assessment (PISA) reports that young girls (15 year old) show higher expectations than boys towards their career. However, only $5 \%$ of the girls in average consider developing a career in computing or engineering. In 2012, the percentage of qualifications awarded to women in the fields of engineering, manufacturing and construction was below 30\%, but higher than in 2000 [1]. In average, women students get higher scores and are more dedicated and so one might expect that it will be possible to attract more and more girls to engineering programs. Understanding the factors that may influence positively the satisfaction and performance of students as well as their outcomes for a professional career are then of the utmost importance, in these fields.

Sonnert and Fox [4] present a quite broad study aiming the comparison between the performance of men and women as undergraduate students in the fields of biology, physical sciences and engineering, by means of grade point averages (GPA). A 16-year period (1981-2004) is considered, using data from almost 500 American universities and colleges. Among those, 45 had special programs for enhancing the participation and performance of women. In the period studied the percentage of women students in the USA raised from 39.1 to $60.1 \%$ in biological and life sciences, from 15 to $22 \%$ in physics and from 10.5 to $20.5 \%$ in engineering, confirming the general tendency for a consistent increasing in women's pursuit of undergraduate studies within science and engineering. Those authors present two-research hypothesis, the first (H1) based in social and cultural factors that may influence women performance and the second (H2) based on the possible effect of special programs (e.g. Women in Engineering) in the performance of women students. Hypotheses H1 was formulated stating that: women undergraduates have higher GPAs than their male counterparts and this GPA difference is larger when the percentage of women is smaller among undergraduate majors, bachelor degree recipients and among faculty members. Many factors may justify that only young women that feel special confidence and are well prepared enter scientific fields. Also a motivational difference is likely to exist, as women students may often feel the challenge to work with an extra-strong dedication in order to achieve higher performances in fields that are traditionally dominated by men. On the other hand, being the minority gender among students and faculty members, once they encounter deeper difficulties they may choose other fields to continue their studies, more easily than their male mates. Also, it might be expected that as the percentage of women students has been rising in science and engineering fields, the GPA advantage has probably decreased. Hypothesis 2 assumed that in settings with special programs for enhancing the performance of women in science and engineering the women's GPA advantage is greater. The results showed a slight but persistent and pervasive advantage for women' GPA with an average difference of 0.1 point (in 1 to 4 score's scale), in $73 \%$ of data points. Differences in GPA did not vary significantly by field. The difference in GPA did not decrease with time as it might be expected neither was influenced by the percentage of women students, when considering all the fields as a group. Only in physical sciences the authors found that the percentage of women in bachelor undergraduate students had the effect previewed by $\mathrm{H} 1$. The influence of the percentage of women as faculty number showed a dubious behavior when two different models were applied to the data. Other questions arise for future analyses, as well as the need of a deeper study on some of the considered effects, as for example the influence of teacher's gender on the dedication of women and men students to work. The fact that in sciences and engineering the professors are mainly male would explain the extra dedication of women students to compensate for their own gender? One important finding was that the type of institution was the factor that influenced more strongly the GPA difference. This also reflects the importance of institutional environment in the relative performance of women and men students. The greater differences in GPA observed in Non-Research - I institutions (according to Carnegie classification) have been partially explained by the authors by the fact that girls having high scores and good performance in their high school are more likely than their colleague males to choose a regional university close to their homes instead of applying to Research I universities. Also the inclusion of special programs in that type of institutions increases the advantage in GPA, validating $\mathrm{H} 2$ at least partially.

Another study covering four countries from the Balkan region [5] was applied to computer science students, from two faculties of Mathematics and two of electrical engineering, with the general goal of looking for significant differences between countries and genders. A group of 355 students was considered (131 female and 224 male). This research used a questionnaire with about 130 questions, covering three main parts: general data about students, questions considering students motivation for studying computer science and finally questions trying to investigate student's ambitions and vision of future career. The results showed more expressive differences between one of the countries (Serbia) and the other three (Albania, Bosnia Herzegovina, FYR Macedonia) than between genders. In very few questions, a significant difference was found between male and female answers, and in the majority of the cases, these differences were observed for Serbian students. This happened for the question "do you think studies positively influenced your intellectual development?", to which male students from Serbia gave significantly lower 
scores than their female colleagues (and all the other students). When inquired about the quality of mathematics' courses the Serbian answers were significantly different from all others and a difference was also found between male and female Serbian students. Girls rated those courses with higher scores. Regarding students' satisfaction towards communication during studies (with lecturers or by eLearning facilities) the Serbian female students gave once again higher scores than their male colleagues. The answers to the question analyzing students' concern for the future showed that girls from countries other than Serbia were more concerned with the future than their male mates. For the question "how well their studies prepared them for the future", there was a more pessimistic perception from Serbian students (no gender significant difference) than for all other countries.

In their study, Amelink and Creamer [6] intended to assess engineering students' satisfaction towards their major and whether they expected to have an engineering professional activity ten years later. Nine institutions with engineering undergraduate programs were considered, with a sample of 1132 male and 484 female students, for a period of five years. The instruments used were an online questionnaire and group interviews in all institutions allowing collection of qualitative data. No significant differences were found between the percentage of female $(89.9 \%)$ and male $(91.7 \%)$ students that were satisfied with the decision of pursuing engineering major. When inquired about the perspective of a long-term career in engineering fields a significant higher percentage of male students (92.4\% against $84.8 \%$ for female students) gave a positive answer. The results of this study point out that some individual and organizational aspects of the engineering major may affect the efficacy of female students and somehow lead to a lower likelihood to imagine themselves in an engineering career some years later. It was concluded that aspects such as weak peer interaction, lack of respect, gender biased behavior and male dominated cultural norms may have a negative influence in female students on the pursuit of a future professional activity in engineering.

The effects of course and instructor characteristics on student evaluation of teaching (SET) have been studied along a seven-semester period (2007 to 2010), in a USA college of engineering (Dwight Look College of Engineering, in TEXAS A\&M University's College Station campus) [7]. Data were collected across 11 major departments, for 419 undergraduate and 397 graduate courses, in several editions, resulting in more than 3900 courses and about 550 instructors. The total number of enrolled students in all those courses was 137,431 . The SET instrument used had eight questions with a 1 to 5 -satisfaction scale. Besides factors such as class size, course level, course type, course grade, instructor experience and academic rank that affected SET, the instructor's gender was also found to influence SET. Female teachers of lower level courses received slightly lower SET scores but no statistical difference was observed for upper level courses.

Pomales-Garcia and Barreto [8] present a study based on the reflections of students in two different engineering design courses that use project-based-learning (PBL). The courses make part of the curriculum of Industrial Engineering (Puerto Rico) and the global aim of this study was to understand the impact of those projects from the students' point of view. One of the specific objectives was to identify possible gender differences in those reflections. A total of 161 undergraduate students have been considered (66 males and 95 females), covering a period of four academic years (2006/7 to 2010/11). The importance of PBL as an integrating tool was confirmed in this study. The results showed no significant differences between the experiences, skills and values highlighted by the students of the two genders. It is important to notice that the percentage of female students in the sample was atypically high, when compared to the majority of engineering programs.

A lot of diverse issues looking for gender differences in engineering fields may be found in research literature but no specific patterns seem to have been found yet. The dynamics and specificity of environmental conditions and programs across different countries and institutions suggest that further research in this area is still of great relevance.

In the present paper the satisfaction of students in different electric and electronic engineering programs and in two different countries is analyzed looking for significant differences in female and male students assessment.

The paper is divided in five sections. Section II presents the research questions, section III describes the materials and methods used, section IV presents the main results and their discussion. The more important ideas and ongoing work are addressed in section $\mathrm{V}$.

\section{RESEARCH QUESTIONS}

To fulfill the main objective of this study, two research question were formulated:

- Are there significant differences between female and male perceptions regarding electrical/electronics engineering course?

- Which are the issues with significant differences?

In the following sections the methodology and discussion of the results obtained are presented in order to answer them.

\section{MATERIALS AND METHODS}

The study follows a quantitative methodology based on quantitative data collected from questionnaires (654 valid for analysis) delivered in the 2nd semester of 2014/15 and in the first semester of 2015/16 academic years. The methodology followed is fully described elsewhere [16]. The questionnaire was grammatical and statistically validated: (1) by a group of students (from which no significant modifications emerged), and (2) by evaluating its internal consistency and reliability by estimating the Cronbach's alpha [16]. The overall Cronbach's $\alpha$ obtained was 0.76 (near 0.8) indicating acceptable/good reliability or good level of internal consistency for the considered scale based on the sample.

\section{A. Sample characterization}

This study considers four Higher Education Institutions (HEIs) distributed as follows:

- Instituto Superior de Engenharia do Porto, ISEP, Portugal (22.6\%); 
- Escola de Engenharia da Universidade do Minho, EEUM, Portugal (18.9\%);

- Instituto Federal de Santa Catarina, IFSC, Brazil, $(32.6 \%)$;

- Universidade Regional de Blumenau, FURB, Brazil $(25.9 \%)$.

Six different studies' programs were chosen: two from ISEP (electrical and computer engineering, ECE-ISEP, and electrical engineering - power systems, EE-PS-ISEP), two from IFSC (electrical engineering, EE-FSC and electronics engineering, EiE-IFSC), one from FURB (Electrical Engineering, EE-FURB) and one from EEUM (Industrial Electronics Engineering and Computers, IEEC-UM) [17]. The choice of these four HEIs was based on the authors' share of common interests regarding engineering education topics, and on previous research joint work as teachers in those HEI. This has facilitated the design of the experiment and data collection. The fact of having the same language in the two countries allowed one single validation of the questionnaire. Beyond these more convenient and practical aspects, it must be pointed out that the four HEI are representative engineering schools in the two countries, from public and private higher education systems, and their academic populations also reflect a wide variety in terms of social, cultural and economical background.

The mean age is 21.7 years $(\mathrm{SD}=4.9$, range $17-55$ years) and most of the students $(67.2 \%)$ are aged 21 years or less.

In all HEI the majority of students $(86.8 \%)$ are male (EEUM 91.2\%, FURB 93.0\%, IFSC 74.8\%, ISEP 93.3\%).

Regarding classes' regime FURB and ISEP are the two HEI that have both day and after work classes. FURB has $87.1 \%$ and ISEP has $19.3 \%$ of students in after work classes. However, all of the HEI have students with student worker status (EEUM 7.2\%, FURB 85.4\%, IFSC 29.4\%, ISEP 18.2\%).

\section{B. Description of the questionnaire}

The questionnaire contains two parts:

- Students' characterization (age, gender, higher education institutions, curricular year, semester, regime, number of registration in the course, and regular/working-student);

- Students' course satisfaction/perception (based on a 5point agreement Likert scale: 1-Strongly Disagree to 5Strongly Agree, with the neutral point being neither disagree nor agree).

The last part of the questionnaire is divided into six groups regarding the following issues:

- Teacher Involvement Perception (TIP) - 8 items;

- Student Interest (SI) - 9 items;

- Student-Teacher interaction (STI) - 6 items;

- Course organization and functioning (COF) - 11 items;

- Infrastructures (Is) - 6 items;

- Overall satisfaction $(\mathrm{OS})-4$ items.
The detailed description of the 44 items is presented in Tables I to VI (see Results and Discussion section).

\section{RESULTS AND DISCUSSION}

The Electrical/Electronics engineering courses are essentially chosen by male students as the tendency identified in the sample characterization $(86.8 \%$ of male students in all HEI). Due to this gender unbalance, the analysis was performed by year (the first three, corresponding to the first cycle of higher education) and including the four institutions/two countries as a whole.

Somehow this is consistent with the results obtained in a previous study supporting that when comparing the two countries, the observed differences are not statistically significant [16].

So, the percentage of male students in first, second and third curricular year is $86.1 \%, 83.3 \%$ and $91.6 \%$, respectively.

The SPSS statistical tool was used for the data analysis. Non-parametric test was considered on the analysis of the primary data: Mann-Whitney $U$ (alternative to the t-test for independent samples), throughout the value of Z-score, to analyze differences between students' perceptions by gender. A significance level of $5 \%$ was considered.

Tables I to VI present the results obtained in the 44 items of the questionnaire distributed in the six groups. The results are in terms of mean values (and the standard deviation) considered all the answers and the results obtained by gender in each year. In the right column of all tables is shown the statistics to verify if the differences in the feedback from male and female students are significant or not.

In general, students' perceptions and satisfaction considering the topics addressed, were higher than 3 and around 4 , in average, indicating positive agreement. The most positive aspect was SI_2: I attend classes regularly (mean=4.5; $\mathrm{SD}=.73$ ) followed by $\overline{\mathrm{SI}} 8$ : The course is making me more and more competent in electrical/electronic engineering area (mean=4.4, $\mathrm{SD}=.77$ ). On the other hand, as the most negative aspect identified by the average of students were: SI 5: I look for teachers outside the class (mean=2.7, SD=1.09), TIP 3: In general, teachers seek to know whether the student has understood the contents taught (mean=3.3, $\mathrm{SD}=.93$ ) and COF_2: The time for each content is adequate (mean=3.4, $\mathrm{SD}=\overline{.95})$

Comparing the female and male students' perceptions, largely, in all the three years, female students were more positive. These results, though obtained with a different tool, are in accordance with results obtained in literature [3],[5], i.e. female students show to be more satisfied than their male mates. However, only in some aspects these differences were significant, in average.

Considering the first year, the following items show significant differences:

- SI_5, I lookfor teachers outside the class;

- SI_7, The course challenges me intellectually; 


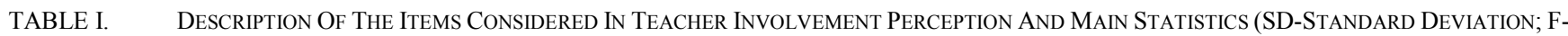
FEMALE; M-MALE)

\begin{tabular}{|c|c|c|c|c|c|}
\hline \multirow{2}{*}{ Item } & \multirow{2}{*}{ Year } & \multicolumn{3}{|c|}{ Mean (SD) } & \multirow{2}{*}{ Statistics Z-score } \\
\hline & & Total & $F$ & $M$ & \\
\hline \multirow{3}{*}{$\begin{array}{l}\text { TIP_1: In general, teachers show interest in teaching the } \\
\text { programmatic contents }\end{array}$} & $1^{\mathrm{st}}$ & $4.1(.77)$ & $4.2(.77)$ & $4.0(.76)$ & $1.73, p=.084$ \\
\hline & $2^{\text {nd }}$ & $3.9(.79)$ & $4.1(.46)$ & $3.9(.84)$ & $.91, p=.364$ \\
\hline & $3^{\text {rd }}$ & $3.7(.83)$ & $3.7(1.14)$ & $3.7(.80)$ & $.66, p=.511$ \\
\hline \multirow{3}{*}{$\begin{array}{l}\text { TIP_2: In general, examples used by teachers help to } \\
\text { understand the contents }\end{array}$} & $1^{\text {st }}$ & $3.9(.76)$ & $4.0(.66)$ & $3.8(.77)$ & $1.42, p=.156$ \\
\hline & $2^{\text {nd }}$ & $3.7(.85)$ & $3.7(.86)$ & $3.7(.86)$ & $.86, \mathrm{p}=.389$ \\
\hline & $3^{\text {rd }}$ & $3.6(.70)$ & $3.9(.99)$ & $3.5(.66)$ & $2.56, \mathrm{p}<.05^{\mathrm{a}}$ \\
\hline \multirow{3}{*}{$\begin{array}{l}\text { TIP_3: In general, teachers seek to know whether the student } \\
\text { has understood the contents taught }\end{array}$} & $1^{\mathrm{st}}$ & $3.3(.93)$ & $3.2(.94)$ & $3.3(.93)$ & $-.94, p=.348$ \\
\hline & $2^{\text {nd }}$ & $3.3(.92)$ & $3.1(.82)$ & $3.4(.94)$ & $-1.59, p=.113$ \\
\hline & $3^{\text {rd }}$ & $3.0(.89)$ & $2.9(1.14)$ & $3.0(.87)$ & $-.18, \mathrm{p}=.86$ \\
\hline \multirow{3}{*}{$\begin{array}{l}\text { TIP_4: In general, teachers aim to contextualize the contents } \\
\text { in a professional perspective }\end{array}$} & $1^{\text {st }}$ & $3.6(.88)$ & $3.7(.90)$ & $3.6(.88)$ & $.93, p=.352$ \\
\hline & $2^{\text {nd }}$ & $3.3(.99)$ & $3.2(.79)$ & $3.3(1.03)$ & $-.83, p=.406$ \\
\hline & $3^{\text {rd }}$ & $3.2(.98)$ & $3.6(1.08)$ & $3.2(.97)$ & $1.70, p=.09$ \\
\hline \multirow{3}{*}{$\begin{array}{l}\text { TIP_5: In general, teachers are available to support the } \\
\text { students }\end{array}$} & $1^{\mathrm{st}}$ & $4.1(.81)$ & $4.2(.79)$ & $4.1(.82)$ & $.74, p=.459$ \\
\hline & $2^{\text {nd }}$ & $4.0(.92)$ & $4.0(.79)$ & $4.0(.94)$ & $.19, \mathrm{p}=.853$ \\
\hline & $3^{\text {rd }}$ & $3.8(.83)$ & $3.9(1,14)$ & $3.8(.80)$ & $1.29, \mathrm{p}=.198$ \\
\hline \multirow{3}{*}{$\begin{array}{l}\text { TIP_6: In general, teachers present challenges to be solved } \\
\text { outside the classroom }\end{array}$} & $1^{\mathrm{st}}$ & $3.8(.89)$ & $3.9(1.04)$ & $3.8(.87)$ & $.31, p=.753$ \\
\hline & $2^{\text {nd }}$ & $3.6(1.05)$ & $3.8(.85)$ & $3.6(1.08)$ & $.96, p=.340$ \\
\hline & $3^{\text {rd }}$ & $3.5(.89)$ & $3.4(1.27)$ & $3.5(.85)$ & $-.11, p=.916$ \\
\hline \multirow{3}{*}{$\begin{array}{l}\text { TIP 7: In general, teachers give feedback of the works } \\
\text { /challenges solved by students }\end{array}$} & $1^{\text {st }}$ & $3.6(.93)$ & $3.6(.97)$ & $3.6(.92)$ & $.25, \mathrm{p}=.803$ \\
\hline & $2^{\text {nd }}$ & $3.5(1.12)$ & $3.4(.76)$ & $3.5(1.07)$ & $-.79, p=.432$ \\
\hline & $3^{\text {rd }}$ & $3.3(.93)$ & $3.5(1.19)$ & $3.2(.90)$ & $1.44, \mathrm{p}=.151$ \\
\hline \multirow{3}{*}{ TIP_8: In general, I assess positively teachers' performance } & $1^{\text {st }}$ & $4.0(.79)$ & $4.1(.73)$ & $4.0(.80)$ & $.72, \mathrm{p}=.473$ \\
\hline & $2^{\text {nd }}$ & $3.8(.77)$ & $3.9(.69)$ & $3.8(.78)$ & $.18, \mathrm{p}=.854$ \\
\hline & $3^{\text {rd }}$ & $3.6(.78)$ & $3.5(1.01)$ & $3.6(.76)$ & $-.09, p=.930$ \\
\hline
\end{tabular}

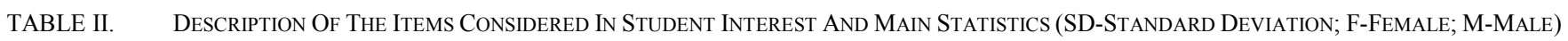

\begin{tabular}{|c|c|c|c|c|c|}
\hline \multirow{2}{*}{ Item } & \multirow{2}{*}{ Year } & \multicolumn{3}{|c|}{ Mean (SD) } & \multirow{2}{*}{ Statistics Z-score } \\
\hline & & Total & $F$ & $M$ & \\
\hline \multirow{3}{*}{ SI_1: I am interested in learning the contents of the course } & $1^{\text {st }}$ & $4.1(.63)$ & $4.6(.54)$ & $4.5(.65)$ & $1.05, p=.295$ \\
\hline & $2^{\text {nd }}$ & $4.4(.68)$ & $4.3(.61)$ & $4.4(.70)$ & $-.49, p=.626$ \\
\hline & $3^{\text {rd }}$ & $4.3(.65)$ & $4.5(.52)$ & $4.2(.65)$ & $1.53, \mathrm{p}=.126$ \\
\hline \multirow{3}{*}{ SI_2: I attend classes regularly } & $1^{\text {st }}$ & $4.5(.73)$ & $4.5(.73)$ & $4.5(.73)$ & $.80, p=.423$ \\
\hline & $2^{\text {nd }}$ & $4.4(.71)$ & $4.5(.63)$ & $4.4(.72)$ & $.64, p=.521$ \\
\hline & $3^{\text {rd }}$ & $4.2(.75)$ & $4.4(.75)$ & $4.2(.76)$ & $.77, p=.440$ \\
\hline \multirow{3}{*}{ SI_3: I pay attention in the classroom } & $1^{\text {st }}$ & $4.2(.70)$ & $4.3(.67)$ & $4.2(.71)$ & $.86, p=.388$ \\
\hline & $2^{\text {nd }}$ & $4.1(.66)$ & $4.3(.67)$ & $4.1(.66)$ & $2.09, \mathrm{p}<.05^{\mathrm{a}}$ \\
\hline & $3^{\text {rd }}$ & $3.9(.72)$ & $4.1(.83)$ & $3.9(.71)$ & $.78, p=.434$ \\
\hline \multirow{3}{*}{ SI_4: I participate in the classroom discussions } & $1^{\text {st }}$ & $3.5(.98)$ & $3.5(1.09)$ & $3.5(.96)$ & $.05, p=.964$ \\
\hline & $2^{\text {nd }}$ & $3.5(.96)$ & $3.6(.99)$ & $3.5(.96)$ & $.10, p=.922$ \\
\hline & $3^{\text {rd }}$ & $3.3(.91)$ & $3.4(.76)$ & $3.3(.93)$ & $.64, p=.520$ \\
\hline \multirow{3}{*}{ SI_5: I look for teachers outside the class } & $1^{\text {st }}$ & $2.8(1.11)$ & $3.3(1.14)$ & $2.7(1.09)$ & $3.41, \mathrm{p}<.005^{\mathrm{a}}$ \\
\hline & $2^{\text {nd }}$ & $3.0(1.13)$ & $3.2(.95)$ & $2.9(1.16)$ & $1.51, \mathrm{p}=.132$ \\
\hline & $3^{\text {rd }}$ & $2.7(1.09)$ & $3.1(1.40)$ & $2.7(1.05)$ & $1.09, p=.274$ \\
\hline \multirow{3}{*}{ SI_6: I use the study room and library } & $1^{\text {st }}$ & $3.8(1.12)$ & $4.0(1.10)$ & $3.7(1.12)$ & $1.84, p=.065$ \\
\hline & $2^{\text {nd }}$ & $3.7(1.12)$ & $4.3(.70)$ & $3.6(1.15)$ & $2.91, \mathrm{p}<.001^{\mathrm{a}}$ \\
\hline & $3^{\text {rd }}$ & $3.7(1.16)$ & $4.5(.76)$ & $3.6(1.17)$ & $2.92, \mathrm{p}<.01^{\mathrm{a}}$ \\
\hline \multirow{3}{*}{ SI_7: The course challenges me intellectually } & $1^{\mathrm{st}}$ & $4.3(.73)$ & $4.5(.88)$ & $4.3(.70)$ & $2.43, \mathrm{p}<.05^{\mathrm{a}}$ \\
\hline & $2^{\text {nd }}$ & $4.3(.76)$ & $4.5(.63)$ & $4.3(.78)$ & $1.23, \mathrm{p}=.220$ \\
\hline & $3^{\text {rd }}$ & $4.2(.78)$ & $4.4(.94)$ & $4.2(.79)$ & $1.57, p=.117$ \\
\hline \multirow{3}{*}{$\begin{array}{l}\text { SI_8: The course is making me more and more competent in } \\
\text { electrical / electronic engineering area }\end{array}$} & $1^{\mathrm{st}}$ & $4.4(.77)$ & $4.5(.63)$ & $4.4(.74)$ & $.74, p=.458$ \\
\hline & $2^{\text {nd }}$ & $4.3(.77)$ & $4.2(.69)$ & $4.3(.79)$ & $-.61, p=.541$ \\
\hline & $3^{\text {rd }}$ & $4.1(.74)$ & $4.1(1.14)$ & $4.1(.70)$ & $.33, p=.744$ \\
\hline \multirow{3}{*}{ SI_9: In general, I identify myself with the course } & $1^{\text {st }}$ & $4.2(.80)$ & $4.1(.84)$ & $4.2(.80)$ & $-.92, p=.357$ \\
\hline & $2^{\text {nd }}$ & $4.2(.81)$ & $4.0(1-10)$ & $4.3(.73)$ & $-.71, p=.479$ \\
\hline & $3^{\text {rd }}$ & $4.2(.76)$ & $4.1(.83)$ & $4.2(.75)$ & $-.33, p=.74$ \\
\hline
\end{tabular}


TABLE III. Description Of The Items Considered In Student-Teacher Interaction AND Main Statistics (SD-STANDARD Deviation; F-Female; M-MALE)

\begin{tabular}{|c|c|c|c|c|c|}
\hline \multirow{2}{*}{ Item } & \multirow{2}{*}{ Year } & \multicolumn{3}{|c|}{ Mean (SD) } & \multirow{2}{*}{ Statistics Z-score } \\
\hline & & Total & $\boldsymbol{F}$ & $M$ & \\
\hline $\begin{array}{l}\text { STI 1: Teachers encourage students to express their views } \\
\text { and doubts }\end{array}$ & $\begin{array}{l}1^{\text {st }} \\
2^{\text {nd }} \\
3^{\text {rd }} \\
\end{array}$ & $\begin{array}{l}3.7(.78) \\
3.7(.87) \\
3.5(.85)\end{array}$ & $\begin{array}{c}\mathbf{4 . 0}(.75) \\
3.6(.73) \\
3.4(1.28)\end{array}$ & $\begin{array}{l}3.7(.78) \\
3.7(.90) \\
3.5(.80)\end{array}$ & $\begin{array}{l}\mathbf{2 . 2 2}, \mathbf{p}=. \mathbf{. 0 5}^{\mathbf{a}} \\
-.45, p=.653 \\
-.21, p=.834\end{array}$ \\
\hline $\begin{array}{l}\text { STI_2: Teachers are receptive to new ideas and different } \\
\text { points of view }\end{array}$ & $\begin{array}{l}1^{\text {st }} \\
2^{\text {nd }} \\
3^{\text {rd }}\end{array}$ & $\begin{array}{l}3.6(.85) \\
3.5(.91) \\
3.4(.89)\end{array}$ & $\begin{array}{c}3.8(.89) \\
3.4(.87) \\
3.2(1.05)\end{array}$ & $\begin{array}{l}3.6(.84) \\
3.6(.92) \\
3.4(.88)\end{array}$ & $\begin{array}{l}1.41, p=.159 \\
-.83, p=406 \\
-.72, p=.472\end{array}$ \\
\hline $\begin{array}{l}\text { STI_3: Teachers generally encourage discussion in the } \\
\text { classroom }\end{array}$ & $\begin{array}{l}1^{\text {st }} \\
2^{\text {nd }} \\
3^{\text {rd }}\end{array}$ & $\begin{array}{l}3.6(.85) \\
3.5(.90) \\
3.3(.81)\end{array}$ & $\begin{array}{c}3.6(.87) \\
3.3(.81) \\
3.2(1.23) \\
\end{array}$ & $\begin{array}{l}3.6(.85) \\
3.5(.91) \\
3.4(.77)\end{array}$ & $\begin{array}{c}.59, p=557 \\
-.98, p=.327 \\
-.32, p=.752\end{array}$ \\
\hline $\begin{array}{l}\text { STI 4: Teachers provide study materials so that students may } \\
\text { train their skills }\end{array}$ & $\begin{array}{l}1^{\text {st }} \\
2^{\text {nd }} \\
3^{\text {rd }}\end{array}$ & $\begin{array}{l}4.3(.82) \\
4.1(.84) \\
4.0(.80)\end{array}$ & $\begin{array}{c}4.1(.91) \\
4.1(.84) \\
4.2(1.05)\end{array}$ & $\begin{array}{l}4.3(.81) \\
4.1(.84) \\
4.0(.77)\end{array}$ & $\begin{array}{l}-.84, p=.400 \\
.20, p=.843 \\
1.83, p=.07\end{array}$ \\
\hline STI_5: Teachers assess students accurately and with fairness & $\begin{array}{l}1^{\text {st }} \\
2^{\text {nd }} \\
3^{\text {rd }}\end{array}$ & $\begin{array}{l}3.8(.87) \\
3.6(.91) \\
3.3(.92)\end{array}$ & $\begin{array}{c}3.8(.94) \\
3.5(.99) \\
3.6(1.28)\end{array}$ & $\begin{array}{l}3.8(.86) \\
3.6(.90) \\
3.2(.88)\end{array}$ & $\begin{array}{l}.06, p=.956 \\
-.89, p=.374 \\
1.69, p=.091\end{array}$ \\
\hline STI_6: In general, the student/teacher interaction is positive & $\begin{array}{l}1^{\text {st }} \\
2^{\text {nd }} \\
3^{\text {rd }}\end{array}$ & $\begin{array}{l}4.0(.72) \\
4.0(.80) \\
3.6(.81)\end{array}$ & $\begin{array}{c}4.0(.66) \\
4.1(.69) \\
3.8(1.05)\end{array}$ & $\begin{array}{l}4.0(.74) \\
3.9(.81) \\
3.6(.79)\end{array}$ & $\begin{array}{c}.62, p=.536 \\
1.16, p=.244 \\
1.05, p=.292\end{array}$ \\
\hline
\end{tabular}

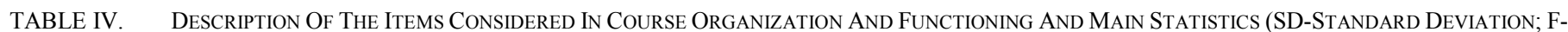
FEMALE; M-MALE)

\begin{tabular}{|c|c|c|c|c|c|}
\hline \multirow{2}{*}{ Item } & \multirow{2}{*}{ Year } & \multicolumn{3}{|c|}{ Mean (SD) } & \multirow{2}{*}{ Statistics Z-score } \\
\hline & & Total & $\boldsymbol{F}$ & $M$ & \\
\hline \multirow{3}{*}{$\begin{array}{l}\text { COF_1: The amount of content covered in the curricular units } \\
\text { is adequate }\end{array}$} & $1^{\text {st }}$ & $3.8(.90)$ & $4.0(.75)$ & $3.7(.92)$ & $1.33, \mathrm{p}=.182$ \\
\hline & $2^{\text {nd }}$ & $3.6(.92)$ & $3.5(.91)$ & $3.7(.92)$ & $-.90, p=.370$ \\
\hline & $3^{\text {rd }}$ & $3.5(.84)$ & $3.7(.73)$ & $3.4(.85)$ & $1.28, \mathrm{p}=.202$ \\
\hline \multirow{3}{*}{ COF_2: The time for each content is adequate } & $1^{\text {st }}$ & $3.4(.95)$ & $3.5(1.00)$ & $3.4(.94)$ & $.58, \mathrm{p}=.565$ \\
\hline & $2^{\text {nd }}$ & $3.3(.84)$ & $3.2(.79)$ & $3.3(.86)$ & $-.63, p=.527$ \\
\hline & $3^{\text {rd }}$ & $3.1(.90)$ & $3.4(1.16)$ & $3.1(.88)$ & $1.43, \mathrm{p}=.152$ \\
\hline \multirow{3}{*}{ COF_3: The suggested bibliography is adequate } & $1^{\text {st }}$ & $3.9(.80)$ & $4.1(.73)$ & $3.8(.81)$ & $1.57, p=.116$ \\
\hline & $2^{\text {nd }}$ & $3.9(.85)$ & $3.8(.69)$ & $3.9(.87)$ & $-1.20, \mathrm{p}=.231$ \\
\hline & $3^{\text {rd }}$ & $3.7(.80)$ & $4.2(.80)$ & $3.7(.79)$ & $2.24, \mathrm{p}<.05^{\mathrm{a}}$ \\
\hline \multirow{3}{*}{$\begin{array}{l}\text { COF_4: The proposed work / exercises are adequate } \\
\text { according the contents of curricular units }\end{array}$} & $1^{\mathrm{st}}$ & $4.1(.75)$ & $4.2(.80)$ & $4.0(.75)$ & $1.59, p=.112$ \\
\hline & $2^{\text {nd }}$ & $3.9(.79)$ & $3.9(.79)$ & $3.9(.80)$ & $.39, p=.695$ \\
\hline & $3^{\text {rd }}$ & $3.7(.80)$ & $4.1(.99)$ & $3.7(.75)$ & $2.46, \mathrm{p}<.05^{\mathrm{a}}$ \\
\hline \multirow{3}{*}{$\begin{array}{l}\text { COF_6: The support materials / resources contributed to my } \\
\text { learning }\end{array}$} & $1^{\text {st }}$ & $4.1(.71)$ & $4.3(.69)$ & $4.1(.71)$ & $1.28, \mathrm{p}=.201$ \\
\hline & $2^{\text {nd }}$ & $4.0(.80)$ & $3.9(.65)$ & $4.0(.83)$ & $-.80, p=.425$ \\
\hline & $3^{\text {rd }}$ & $3.9(.66)$ & $4.2(.89)$ & $3.9(.64)$ & $1.63, p=.104$ \\
\hline \multirow{3}{*}{$\begin{array}{l}\text { COF_7: The practical and laboratory components of the } \\
\text { course are adequate }\end{array}$} & $1^{\text {st }}$ & $3.9(.85)$ & $4.1(.98)$ & $3.9(.83)$ & $1.69, p=.091$ \\
\hline & $2^{\text {nd }}$ & $3.7(.90)$ & $3.6(.86)$ & $3.7(.91)$ & $-.65, p=.517$ \\
\hline & $3^{\text {rd }}$ & $3.6(.88)$ & $3.9(.76)$ & $3.5(.89)$ & $1.75, \mathrm{p}=.081$ \\
\hline \multirow{3}{*}{$\begin{array}{l}\text { COF_8: Teachers try to relate the contents with other } \\
\text { curricular units }\end{array}$} & $1^{\text {st }}$ & $3.7(.83)$ & $3.8(.86)$ & $3.7(.83)$ & $1.02, p=.306$ \\
\hline & $2^{\text {nd }}$ & $3.5(.96)$ & $3.2(1.01)$ & $3.6(.94)$ & $-1.58, \mathrm{p}=.116$ \\
\hline & $3^{\text {rd }}$ & $3.6(.80)$ & $4.1(.76)$ & $3.5(.79)$ & $2.26, \mathrm{p}<.05^{\mathrm{a}}$ \\
\hline \multirow{3}{*}{$\begin{array}{l}\text { COF_9: The syllabus of the curricular units is well articulated } \\
\text { with the previous knowledge acquired }\end{array}$} & $1^{\text {st }}$ & $3.6(.83)$ & $3.7(.87)$ & $3.6(.82)$ & $1.50, p=.134$ \\
\hline & $2^{\text {nd }}$ & $3.5(.90)$ & $3.3(.85)$ & $3.6(.91)$ & $-1.61, p=.108$ \\
\hline & $3^{\text {rd }}$ & $3.5(.85)$ & $3.5(1.12)$ & $3.5(.83)$ & $.63, \mathrm{p}=.532$ \\
\hline \multirow{3}{*}{ COF_10: In general, the curricular units meet my expectations } & $1^{\text {st }}$ & $3.8(.80)$ & $3.9(.80)$ & $3.8(.80)$ & $.87, p=.386$ \\
\hline & $2^{\text {nd }}$ & $3.8(.75)$ & $3.7(.72)$ & $3.8(.75)$ & $-1.01, p=.311$ \\
\hline & $3^{\text {rd }}$ & $3.5(.79)$ & $3.9(1.03)$ & $3.5(.75)$ & $1.74, \mathrm{p}=.082$ \\
\hline \multirow{3}{*}{ COF_11: The course is well organized } & $1^{\text {st }}$ & $3.8(.92)$ & $3.7(.87)$ & $3.8(.93)$ & $.49, p=.626$ \\
\hline & $2^{\text {nd }}$ & $3.4(.95)$ & $3.4(.97)$ & $3.4(.95)$ & $.63, p=.526$ \\
\hline & $3^{\text {rd }}$ & $3.3(.91)$ & $3.5(.97)$ & $3.3(.91)$ & $1.55, \mathrm{p}=.122$ \\
\hline
\end{tabular}


TABLE V. Description Of The Items Considered In Infrastructure And Main Statistics (SD-STANDARD DeViation; F-Female; M-Male)

\begin{tabular}{|c|c|c|c|c|c|}
\hline \multirow{2}{*}{ Item } & \multirow{2}{*}{ Year } & \multicolumn{3}{|c|}{ Mean (SD) } & \multirow{2}{*}{ Statistics Z-score } \\
\hline & & Total & $\boldsymbol{F}$ & $M$ & \\
\hline Is_1: Classrooms are adequate & $\begin{array}{l}1^{\text {st }} \\
2^{\text {nd }} \\
3^{\text {rd }}\end{array}$ & $\begin{array}{c}3.7(1.00) \\
3.7(.99) \\
3.5(.86)\end{array}$ & $\begin{array}{c}3.7(1.03) \\
3.9(.72) \\
3.8(.98) \\
\end{array}$ & $\begin{array}{c}3.7(.99) \\
3.7(1.03) \\
3.4(.84)\end{array}$ & $\begin{array}{c}.08, p=.937 \\
.88, p=.378 \\
1.63, p=.104\end{array}$ \\
\hline Is_2: Study rooms exist and are adequate & $\begin{array}{l}1^{\text {st }} \\
2^{\text {nd }} \\
3^{\text {rd }}\end{array}$ & $\begin{array}{c}3.8(.93) \\
3.4(1.12) \\
3.6(.98)\end{array}$ & $\begin{array}{l}3.8(1.01) \\
3.5(1.09) \\
3.9(1.07)\end{array}$ & $\begin{array}{c}3.8(.92) \\
3.4(1.13) \\
3.5(.97)\end{array}$ & $\begin{array}{c}.37, p=.715 \\
.20, p=.846 \\
1.35, p=.178\end{array}$ \\
\hline Is_3: Network infrastructures and IT support are adequate & $\begin{array}{l}1^{\text {st }} \\
2^{\text {nd }} \\
3^{\text {rd }}\end{array}$ & $\begin{array}{l}3.6(1.00) \\
3.2(1.05) \\
3.1(1.12)\end{array}$ & $\begin{array}{c}3.7(1.00) \\
3.1(.96) \\
3.4(1.22)\end{array}$ & $\begin{array}{l}3.6(1.01) \\
3.2(1.07) \\
3.0(1.11)\end{array}$ & $\begin{array}{c}.85, p=.393 \\
-.41, .681 \\
1.40, p=.162\end{array}$ \\
\hline Is_4: Library space and bibliographic material are adequate & $\begin{array}{l}1^{\text {st }} \\
2^{\text {nd }} \\
3^{\text {rd }} \\
\end{array}$ & $\begin{array}{l}3.9(.88) \\
3.5(1.03 \\
3.6(.93) \\
\end{array}$ & $\begin{array}{l}4.0(.94) \\
3.6(.87) \\
3.7(.98) \\
\end{array}$ & $\begin{array}{c}3.9(.87) \\
3.5(1.07) \\
3.6(.92)\end{array}$ & $\begin{array}{l}.63, p=.528 \\
.08, p=.937 \\
.15, p=.882\end{array}$ \\
\hline $\begin{array}{l}\text { Is_5: The laboratory support infrastructures concerning } \\
\text { available equipment are adequate }\end{array}$ & $\begin{array}{l}1^{\text {st }} \\
2^{\text {nd }} \\
3^{\text {rd }}\end{array}$ & $\begin{array}{c}4.0(.93) \\
3.7(1.10) \\
3.6(.96)\end{array}$ & $\begin{array}{l}4.2(.89) \\
3.8(.86) \\
3.9(.77)\end{array}$ & $\begin{array}{c}3.9(.94) \\
3.7(1.15) \\
3.6(.97)\end{array}$ & $\begin{array}{c}1.88, p=.075 \\
.03, .975 \\
1.12, p=.310\end{array}$ \\
\hline $\begin{array}{l}\text { Is_6: The laboratory support infrastructures concerning } \\
\text { materials/components are adequate }\end{array}$ & $\begin{array}{l}1^{\text {st }} \\
2^{\text {nd }} \\
3^{\text {rd }}\end{array}$ & $\begin{array}{c}3.9(.88) \\
3.7(1.09) \\
3.6(.87)\end{array}$ & $\begin{array}{l}4.1(.91) \\
3.8(.81) \\
3.9(.77)\end{array}$ & $\begin{array}{c}3.9(.87) \\
3.7(1.14) \\
3.6(.88)\end{array}$ & $\begin{array}{c}1.66, p=.098 \\
.04, p=.969 \\
1.25, p=.213\end{array}$ \\
\hline
\end{tabular}

TABLE VI. Description Of The Items Considered In Overall Satisfaction And Main Statistics (SD-Standard Deviation; F-Female; M-Male)

\begin{tabular}{|c|c|c|c|c|c|}
\hline \multirow{2}{*}{ Item } & \multirow{2}{*}{ Year } & \multicolumn{3}{|c|}{ Mean (SD) } & \multirow{2}{*}{ Statistics } \\
\hline & & Total & $\boldsymbol{F}$ & $M$ & \\
\hline $\begin{array}{l}\text { OS_1: I am satisfied with the environment and working } \\
\text { conditions of the school }\end{array}$ & $\begin{array}{l}1^{\text {st }} \\
2^{\text {nd }} \\
3^{\text {rd }}\end{array}$ & $\begin{array}{l}4.0(.74) \\
3.7(.92) \\
3.7(.65)\end{array}$ & $\begin{array}{l}4.1(.82) \\
3.8(.76) \\
3.7(.73)\end{array}$ & $\begin{array}{l}4.0(.73) \\
3.7(.95) \\
3.7(.64)\end{array}$ & $\begin{array}{l}.90, p=369 \\
.56, p=.573 \\
.52, p=.602\end{array}$ \\
\hline $\begin{array}{l}\text { OS_2: I am satisfied with the academic environment (cultural, } \\
\text { sporting and recreational activities) }\end{array}$ & $\begin{array}{l}1^{\text {st }} \\
2^{\text {nd }} \\
3^{\text {rd }} \\
\end{array}$ & $\begin{array}{c}3.8(.87) \\
3.6(1.12) \\
3.5(.93) \\
\end{array}$ & $\begin{array}{c}3.9(.86) \\
3.5(.91) \\
3.8(1.05) \\
\end{array}$ & $\begin{array}{c}3.8(.86) \\
3.6(1.04) \\
3.5(.92)\end{array}$ & $\begin{array}{r}.81, p=.420 \\
-.95, p=.342 \\
1.34, p=.179\end{array}$ \\
\hline OS_3: In general, I am satisfied with the course & $\begin{array}{l}1^{\text {st }} \\
2^{\text {nd }} \\
3^{\text {rd }} \\
\end{array}$ & $\begin{array}{l}4.1(.77) \\
4.0(.81) \\
3.8(.72) \\
\end{array}$ & $\begin{array}{l}4.3(.70) \\
3.9(.84) \\
4.0(.78)\end{array}$ & $\begin{array}{l}4.1(.78) \\
4.0(.80) \\
3.8(.72)\end{array}$ & $\begin{array}{l}1.56, p=.119 \\
-.36, p=.717 \\
1.18, p=.237\end{array}$ \\
\hline $\begin{array}{l}\text { OS_4: I recommend the Electronic Engineering course of this } \\
\text { institution to a friend }\end{array}$ & $\begin{array}{l}1^{\text {st }} \\
2^{\text {nd }} \\
3^{\text {rd }}\end{array}$ & $\begin{array}{l}4.3(.78) \\
4.2(.88) \\
4.0(.80)\end{array}$ & $\begin{array}{l}4.6(.59) \\
4.1(.94) \\
4.2(.89)\end{array}$ & $\begin{array}{l}4.3(.80) \\
4.3(.87) \\
4.0(.80)\end{array}$ & $\begin{array}{l}\mathbf{2 . 3 3}, \mathbf{p}<. \mathbf{0 5}^{\mathbf{a}} \\
-.89, p=.373 \\
1.12, p=.262\end{array}$ \\
\hline
\end{tabular}

a. Statistically significant

- STI_1, Teachers encourage students to express their views and doubts;

- OS 4, I recommend the Electronic Engineering course of this institution to a friend.

In the second year, different items show significant differences, namely:

- SI_3, I pay attention in the classroom;

- SI_6, I use the study room and library.

And in the third year, the following items:

- TIP_2, In general the examples used by teachers help to understand the contents;

- SI_6, I use the study room and library;

- COF_3, The suggested bibliography is adequate;

- $\mathrm{COF} 4$, The proposed work / exercises are adequate according the contents of curricular units;

- $\quad$ COF_8, Teachers try to relate the contents with other curricular units.
In all of the above items male students gave more negative answers, which might indicate that boys are more demanding, requiring more from their courses and teachers.

Also, girls seemed to be more attentive in classes and they appear to be more dedicated to the study (they looked for teachers outside the classroom and they used the study room and library). Also, these results appeared to follow the research questions posed by Sonnert and Fox work [4].

\section{FINAL REMARKS AND ONGOING WORK}

The goal of the study presented in this paper was to measure the gender effect and impact in students' perceptions and satisfaction in Electrical/Electronic Engineering courses.

Following this objective, two research questions were defined:

- Are there significant differences between female and male perceptions regarding electrical/electronics engineering course?

- Which are the items with significant differences? 
The analyses were based on satisfaction/perception questionnaires (in a 1 to 5 Likert scale) distributed in six courses of two Portuguese and two Brazilian HEIs. The first three curricular years were considered, corresponding to the $1 \mathrm{st}$ cycle of higher education.

There are some differences in students' perception/degree of satisfaction towards the course that are significant. The items where gender differences were encountered differ from one year to another.

The numerical data gathered in the present study, highlight situations and in some way indicate priorities. It is common perception that electrical/electronic engineering is traditionally male but more and more women chose this area of knowledge for a professional career. As underlined in Jolly's work [18], male university students feel that their university education has prepared them for a research career while female students struggle to just fit in.

With this work it is not intended to propose guidelines but rather to stretch differences and provide more awareness about this topic helping to eliminate stereotyped images of engineering, creating changes that would ultimately attract a more diverse workforce [18].

Based on quantitative results, a qualitative analysis will be carried on providing an opportunity for students to speak in first person about their experience.

Also, the analysis performed in these HEI in Portugal and Brazil was the kick-off of an extensive study considering other engineering courses, other HEI and others countries.

Everyone's the same, yet everyone's different.

\section{ACKNOWLEDGMENT}

The authors would like to express their acknowledgments to the higher education institutions and to all the students and teachers who accepted to collaborate in this study.

\section{REFERENCES}

[1] OECD (2015, March). "Education and employment - what are the gender differences?." Education Indicators in Focus. [On-line]. Available: http://www.oecd.org/education/EDIF-2015-No-30-ENG.pdf [25.April.2017].

[2] S. Vincent-Lancrin. (2008). "The Reversal of Gender Inequalities in Higher Education: An On-Going Trend." In Higher Education to 2030, Volume 1: Demography, pp. 265-298. OECD Centre for Educational Research and Innovation. doi: 10.1787/9789264040663-en

[3] Y. K. Kim and L. J. Sax. "Student-Faculty Interaction in Research Universities: Differences by Student Gender, Race, Social Class, and First-Generation Status." Research in Higher Education, vol. 50, pp. 437-459, 2009. doi: 10.1007/s11162-009-9127-x

[4] G. Sonnert and M. F. Fox. "Women, Men, and Academic Performance in Science and Engineering: The Gender Difference in Undergraduate
Grade Point Averages." The Journal of Higher Education, vol. 83, no.1, pp. 73-101, 2012. doi: 10.1353/jhe.2012.0004

[5] Z. Putnik, I. Štajner-Papuga, M. Ivanović, Z. Budimac and K. Zdravkova. "Gender related correlations of computer science students." Computers in Human Behavior, vol. 69, pp. 91-97, 2017. doi: 10.1016/j.chb.2016.12.009

[6] C. T. Amelink and E. G. Creamer. "Gender Differences in Elements of the Undergraduate Experience that Influence Satisfaction with the Engineering Major and the Intent to Pursue Engineering as a Career." Journal of Engineering Education, vol. 99, no.1, pp. 81-92, 2010. doi: 10.1002/j.2168-9830.2010.tb01044.x

[7] M. D. Johnson, A. Narayanan, and W. J. Sawayac. "Effects of Course and Instructor Characteristics on Student Evaluation of Teaching across a College of Engineering." Journal of Engineering Education, vol. 102, No. 2, 2013, pp. 289-318, DOI: 10.1002/jee.20013

[8] C. Pomales-García and K. C. Barreto. "Comparative analysis of student self-reflections on course projects." European Journal of Engineering Education, vol. 39, no. 6, pp. 685-699, 2014 . doi: 10.1080/03043797.2014.895706

[9] D. R. Primé, B. L. Bernstein, K. G. Wilkins, and J. M. Bekki. "Measuring the Advising Alliance for Female Graduate Students in Science and Engineering: An Emerging Structure." Journal of Career Assessment, vol. 23, no. 1, pp. 64-78, 2015. doi: $10.1177 / 1069072714523086$

[10] J. C. Kamphorst, W. H. A. Hofman, E. P. W. A. Jansen, and C. Terlouw. "Explaining Academic Success in Engineering Degree Programs: Do Female And Male Students Differ?." Journal of Engineering Education, vol. 104, no. 2, pp. 189-211, , 2015. doi:10.1002/jee.20071

[11] L. J. Sax, A.N. Bryant and C. E. Harper. "The Differential Effects of Student-Faculty Interaction on College Outcomes for Women and Men." Journal of College Student Development, vol. 46, no. 6, pp. 642-657, 2005. doi: 10.1353/csd.2005.0067 DOI: 10.1353/csd.2005.0067

[12] M. W. Ohland, S. D. Sheppard, G. Lichtenstein, O. Eris, D. Chachra, and R. A. Layton. "Persistence, Engagement, and Migration in Engineering Programs." Journal of Engineering Education, vol. 97, no.3, pp. 259-278, 2008. doi: 10.1002/j.2168-9830.2008.tb00978.x

[13] R. A. Calvo, L. Markauskaite and K. Trigwell. "Factors Affecting Students' Experiences and Satisfaction about Teaching Quality in Engineering." Australasian Journal of Engineering Education, vol. 16, no.2, pp. 139-148, 2010. doi: 10.1080/22054952.2010.11464049

[14] R. Tucker. "Sex does not matter: gender bias and gender differences in peer assessments of contributions to group work." Assessment \& Evaluation in Higher Education, vol. 39, no. 3, pp. 293-309, 2014. doi:10.1080/02602938.2013.830282

[15] S. Briggs. "An exploratory study of the factors influencing undergraduate student choice: the case of higher education in Scotland." Studies in Higher Education, vol. 31, no 6, pp. 705-722, 2006. doi: 10.1080/03075070601004333

[16] C. P. Leão, F. Soares, R. Hausmann, A. Guedes, M. T. S. Esteves, G. Alves, I.B. Pereira and C.A. Petry. "Portuguese and Brazilian students perceptions regarding the flow of knowledge in their courses: Two different realities?." In Proceedings of the 2nd International Conference of the Portuguese Society for Engineering Education (CISPEE IEEE), 2016, pp. 1-6.

[17] C. P. Leão, F. Soares, A. Guedes, T. Sena-Esteves, G. Alves, I. BrásPereira, R. Hausmann, C. Petry. "Freshman's Perceptions in Electrical/Electronic Engineering Courses: early findings." In Proceedings of the 3rd International Conference on Technological Ecosystems for Enhancing Multiculturality (TEEM'15). Eds. G. Alves \& M. C. Felgueiras, Porto, Portugal, 2015, pp. 361-367. doi:http://dx.doi.org/10.1145/2808580.2808634

[18] L. Jolly. "Women, Men and the Practice of Engineering." In Proceedings of the 2007 AaeE Conference, Melbourne, 2007. 